DOI: 10.20472/IAC.2018.038.045

MUGE LEYLA YILDIZ

Marmara University, Turkey

SELAY GIRAY YAKUT

Marmara University, Turkey

\title{
GENERATIONAL DIFFERENCES IN CAREER EXPECTATIONS: AN EMPIRICAL STUDY AMONG TURKISH WORKERS
}

\begin{abstract}
:
A new generation of employees with different needs and new expectations of management is entering the workplace. They are known by many names, but most will recognize them as the Nexters or Generation Y. It is essential to be understood about generational differences in organizations. Career expectations play a major role in determining career outcomes. It is important to understand what generations expect in their career path. This study aims to investigate career expectations of Generation X and $Y$ in Turkish society. The sample of this study consisted of 1200 workers in differnet sectors in Turkey. The results represent the Turkish generational differences in career expectations.
\end{abstract}

\section{Keywords:}

Millenials, generation cohort, career expectations

JEL Classification: M12, M14, J24 